Dr. NabarRo wished to thank the speakers for their papers, which he did not think lent themselves to a great deal of discussion. There was one point in Dr. Semon's paper which he questioned, and that was his statement that during pregnancy the Wassermann reaction frequently became negative. He knew it was frequently stated, but it was not borne out in his own experience. He had examined a considerable number of women and could not remember many of them becoming negative, a few might become less positive if they were being treated.

He had not seen a large number of cases of tuberculosis in syphilitic children. He could remember one case of tubercular meningitis where the fluid gave a positive Wassermann. Also two children who showed tuberculous glands in the neck; but it was rather interesting that adenitis might be the only symptom of congenital syphilis, so that if one came across a child with enlarged glands one should not omit to do a Wassermann. He had one very interesting case of a child who had a gummatous condition of the cheek which persisted for about two years, it improved under treatment, but the mother did not bring him to complete the course; he had another case of a gummatous ulceration of the scrotum.

As regarded tuberculosis itself he did not suppose that amongst nearly I,Ooo cases of congenital syphilis he had studied there were 5 complicated with tuberculosis.

Dr. Trail's cases were very interesting, especially because the pulmonary tuberculosis appeared to be benefited by the syphilis treatment. Syphilis is known to produce fibrosis and this would tend to arrest the progress of the tuberculous infection. He did not think it would be wise, however, to suggest syphilis as a form of treatment for pulmonary tuberculosis!

Dr. BUCKLeY Sharp said that Dr. Semon had mentioned an enormous number of pathological conditions which he would notand most of them would not-recognise if they actually met them. There were one or two points he wished to touch on in his paper. The first was the question of Bazin's disease in which Dr. Semon suggested the majority gave a Mantoux reaction. He took it that most cases occurred in young women, at any rate in the teens, and he would have thought that the majority of these would give a positive Mantoux reaction in any event, and that this was not a really valuable diagnostic point in favour of a tuberculous origin. If, on the other hand, a vascular condition was to be considered, he would like to ask whether in these cases one also found in a significant number a condition known 


\section{PULMONARY TUBERCULOSIS AND SYPHILIS}

as erythrocyanosis frigida crurum puellareum, which was probably the most common type of vascular disorder in the legs of young females. It had been treated by sympathectomy with some benefit, although he had never been able to persuade any of his own patients to have the operation done. Sympathectomy was more effective in vascular disorders of the lower limbs than of the upper, the tendency being towards recurrence in the latter.

Dr. Semon had contrasted various stages of syphilis with various stages of tuberculosis, pointing out the primary stages of both. There was a secondary stage of tubercle described, in which one of the manifestations was sometimes erythema nodosum, which in children was more commonly tuberculous than rheumatic.

Dr. Sharp had been very interested to hear Dr. Trail's remarks on syphilitic fibrosis of the lung because Dr. Trail had sent a case to the Royal Northern from City Road of that condition and showed him the X-rays. The patient had a certain amount of anti-syphilitic treatment, and he thought he was right in saying that the repeat $X$-ray taken after, at any rate, some treatment did not show an actual change in the fibrosis. The patient had now disappeared so that he had not been able to follow him up.

Dr. Sharp had had another case referred in which bronchitis was attributed to syphilis, but when he went into his history he found that the bronchitis had been troublesome before syphilis was contracted. When he was a house surgeon his chief always used to teach that tubercle was born on the bed made by syphilis; he had always been sceptical of this teaching and Dr. Trail had convinced him that it was untrue.

Dr. Sharp said he would like to have Dr. Trail's views as to how much benefit in the tuberculous patient was due to his having syphilis, and how much due to the treatment. Suppose a case of tuberculosis had not got syphilis, should it be given anti-syphilitic treatment? Would it do any good? There was an analogy that some skin lesions originally thought to be syphilitic and afterwards thought to be tuberculous had probably benefited by being given intravenous arsenical injections, suggesting that this treatment might benefit the lung disease even if the patient had not got syphilis.

DR. Hamilton Wilkie said how much he had enjoyed the two addresses. With regard to the first speaker's cases he had to admit that in one or two he would have given a different diagnosis. The skin condition of the soles of the feet was one. During the last eighteen months he had seen 7 cases of hyperkeratosis. Four were due to the gonococcus, one to the staphylococcus, one to a Gram-positive bacillus, and one of unknown origin. All 7 had a concurrent toxic conjunctivitis, urethritis, and rheumatism. The Wassermann reactions were all negative. The last coloured photograph shown was a lesion at the elbow which Dr. Semon described as tubercular. Dr. Hamilton Wilkie confessed that he would have thought first of a circinate syphilide and then a tubercular condition.

DR. MARY Liston said there was very little to discuss in the points which had been put forward but there were one or two points on treatment and diagnosis which from her own experience she wished to put forward. To her mind the present-day treatment of syphilis made one question whether all was being done that could be done to 


\section{BRITISH JOURNAL OF VENEREAL DISEASES}

prevent syphilis and shorten the duration of treatment, and whether too much reliance was not being placed on drugs. In the treatment of tuberculosis the environment and diet of the patient were looked after, as well as supervision of contacts. The importance of these measures was obvious, the potency and the number of bacteria were lessened by securing sunlight and fresh air. The resistance of the patient was improved by a diet rich in vitamins so that a healthy epithelial surface was gradually established to prevent the further entrance of germs into the body. In syphilis enough had not been done to prevent infection by establishing healthy surroundings and increasing the patients' natural resistance by attention to their habits and diet. Among the Bedouins in Iraq, where there was extreme poverty and great lack of hygiene, but no sexual immorality, 90 per cent. of the population suffered from "Bejel" or endemic syphilis. They were told that there was no scientific evidence in man that $S$. pallida could penetrate intact skin or mucous membrane, and in this way she thought a diet rich in certain vitamins helped.

It was important, if cure was to result, that the cause of lesions should be known. In tuberculosis it was known that an injection of dead tubercle bacilli could cause a typical tubercle and certain general effects if soil were suitable, but in syphilis it was still unknown what toxins produced a gumma or the more diffuse lesions such as were met with in locomotor ataxia. Nothing was known about the action of spirochætes beyond their mere presence in syphilis.

Too little notice, if any at all, was taken of the other germs which were constantly associated with spirochætes-besides $S$. pallida's occasional association with tubercle bacilli. Bacteria which could produce toxins were to be found in any syphilitic case, in one or other of the absorptive areas of the body. She had done some investigation into the varieties of bacteria associated with $S$. pallida and was sometimes surprised to find diphtheria bacilli as well as virulent streptococci in cases where their presence was totally unsuspected. Toxic bacteria were to be found in any syphilitic case. Spirochætes-many indistinguishable from $S$. pallida-were to be found in the region of unhealthy teeth and gums, and she would have liked to know the condition of the mouth in the patients alluded to in the lecture.

She was glad to have the opportunity to direct attention to the lack of any reliable scientific evidence which would make one certain that $S$. pallida was the true cause of the lesions of syphilis beyond the fact that possibly "Adhesion Phenomenon " might play some part in their production.

DR. D. ERSKINE very much appreciated both the papers, especially Dr. Semon's when he drew attention to the appearance of the eruption in syphilis and tuberculosis. With regard to ulcers of the leg, he thought the Wassermann was unreliable from the point of view of diagnosis, as it was so often negative in cases of gummatous ulceration here, while the results of the Mantoux test were so frequently positive in the adult that it was unlikely to be of help in differentiation. In reference to Dr. Trail's paper, he said he was very encouraged to hear of the favourable outlook in cases of double infection, but he wondered whether the arsenical compounds used for syphilis might exert an action similar to that claimed for Sanocrysin in tuberculosis ; this might explain the improved prognosis in these cases. 


\section{PULMONARY TUBERCULOSIS AND SYPHILIS}

Dr. SCHNEIDER-GREEN said there were some very interesting points in Dr. Semon's paper, especially with regard to Bazin's disease. As pointed out by Telford, if it were granted that the giant cells were of the nature of foreign body giant cells, the foreign body being necrosing fat, then the picture was not necessarily typical of tuberculosis. It was well known that the giant cells were very often missing in erythema induratum, and in the group of dermatoses which included the lipophagous granulomata the histological picture was nearly always the same. He would be interested to hear what Dr. Semon thought about this question of the ætiology of Bazin's disease.

The President (Colonel L. W. Harrison) expressed his great appreciation of both papers, from which he had learnt a great deal. He was bound to admit he felt some scepticism about the tendency of pregnancy to make Wassermann reactions negative; on the contrary, he was sure that in most cases the tendency was in the other direction.

He wished to ask Dr. Semon whether Bazin's disease had become more frequent since ladies took to exposing their calves.

Dr. Trail had given him great comfort in confirming his impression that one could go ahead with arsephenamine treatment of the tubercular case without fear of its making the tubercular process worse.

Dr. Semon, in reply, said there seemed to be a considerable divergence of opinion as regarded the presence of a positive or negative Wassermann in pregnancy. He was only sorry that Colonel Burke was not present, because Dr. Semon believed he had strong views on the matter, and had definitely stated that the Wassermann tended to become negative in pregnancy. He himself was quite willing to admit that it might be a false negative.

He wished to ask Dr. Nabarro whether he had ever come across a case of primary tuberculous complex?-i.e., a tuberculous chancre with local gland involvement. (DR. NABARRo: " No.")

DR. SEMON further said that Dr. Sharpe raised an interesting point, and he agreed that the two conditions could be simultaneous and he was on the point of being converted by Professor Telford, whose original paper was read in Manchester last year, to the view that Bazin's disease was a misnomer, and was not a tuberculous infection. The people who had it were usually very well. What was a little difficult to explain was that in some cases he had kept them well with tubercle injections. They used to put their cases to bed until they healed, but some were kept up, and in those cases, as far as he knew, there was not a single failure. He was " on the fence" as regards the pathogenesis of the condition, and he thought that an increasing number of authorties regarded it as non-tuberculous, although it had been considered so for eighty years.

Regarding the case of plantar hyperkeratosis, there again he was only convinced that it was a syphilitic lesion, because it cleared up with N.A.B., and had a positive Wassermann. He admitted that the appearance was much more like a gonococcal hyperkeratosis than anything else. With regard to the lupus vulgaris, he could not agree that this was not like a syphilitic lesion, perhaps the colour had not come out well, but if it was seen in daylight there would be no hesitation in saying that it was tuberculous.

I8I 


\section{BRITISH JOURNAL OF VENEREAL DISEASES}

Answering the point as to whether Bazin's disease was on the increase, he could not say that it was.

DR. TRAIL, also in reply, said with reference to the question as to whether treatment of tuberculosis by anti-syphilitic treatment was justifiable or would produce any end result, that he could not say because he did not know anyone who had tried it. On the same lines another speaker raised the point of sanocrysin. A Frenchman published a case of syphilis who had also active tuberculosis, and he tried sanocrysin and the patient made a miraculous recovery. But the practitioner in question had been so contradicted that the speaker could not come to any conclusion. On the other hand, he thought gold therapy was of enormous value in re-exacerbation of fibroid tubercle, and in his experience it had been used with good results. He could show a case of a woman with bilateral cavitation; he put her on two complete courses of Solganol B, and on tomograph examination no cavitation at all was to be seen.

Dr. Liston had raised the point about sanatorium treatment, and pointed out that the same attention was not given to syphilitics. Dr. Trail wished to point out that tuberculous patients who were not treated in a sanatorium had a definitely less chance of survival, as had been proved by statistics, and his group was not quite comparable with the ordinary syphilitic patient, who had not got tuberculosis, and did not need sanatorium treatment. It would not be a very good thing to put syphilitics on a strict diet and régime.

Someone raised a question about the various treatments of tuberculosis in various stages of syphilis which was quite interesting. No one need fear the treatment of secondary syphilis in pulmonary tuberculosis, nor fear the carrying out of the full treatment of both. He had had the experience that the patient was mildly disturbed, but, on the other hand, when there were cardiovascular symptoms present one must be careful ; the patient then came under the same category as the man whom you would discuss for operation on his chest, whose cardiovascular symptoms had to be considered apart from his actual lesion. 